\title{
Pemikiran Hasbi Ash-Shiddiqy Tentang Fiqh Zakat Di Indonesia
}

\author{
Herman, Abd. Halim Talli, dan Kurniati \\ Universitas Islam Negeri Alauddin Makassar \\ Jl. H. M. Yasin Limpo No. 36 Kampus II UIN Alauddin Makassar, Samata-Gowa, \\ Sulawesi Selatan, Indonesia 92113 \\ man.her1007@gmail.com
}

\begin{abstract}
Muhammad Hasybi is a self-taught, he masters education is only around one year more at the AlIrsyad. school (1926). However, through this short formal education he was able to set himself apart as a thinker. Hasybi's expertise in ijtihad, he was able to introduce himself as a well-known intellectual in international world. Related to the results of Hasbi's ijtihad, it describes: The state of Indonesian fiqh can be seen in Hasbi's ijtihad on zakat by referring to the view of Abu Hanifa which is different from the opinion of the majority of scholars - Hasybi is of the opinion that machines Production in large factories must be zakat. This view is quite relevant with the context of a country builder that requires a lot of capital. Hasybi's opinion on zakat is left to the government for manage it. Because, for Hasbi, zakat is the same as zakat development for the welfare of society, both nonMuslims and non-Muslims Muslim. Therefore, the collection of zakat should also not only addressed to the Muslims, but also to the non-Muslim. Then, the principle of zakat, which is taken on the type of property that is growing, assets that have sufficient nishab, and zakat assets.
\end{abstract}

Keywords: Thought, Hasybi Ash-Siddiqy, Ijtihadi Fiqh Zakat

\begin{abstract}
Abstrak
Muhammad Hasybi adalah seorang otodidak, ia menempu pendidikan hanya birkisar satu tahun lebih di bangku sekolah Al-Irsyad (1926). Namu, melalui pendidikan formal yang singkat tersebut ia maтри menojolkan dirinya menjadi seorang pemikir. Keahlian Hasbi dalam ijtihad ia mampu memperkenalkan diri sebagai intelektul yang tekenal di dunia internasional. Terkait dengan hasil ijtihad Hasybi mennggambarkan keadaan fiqh ke-Indonesiaan dapat dilihat pada ijtihad Hasbi tentang zakat dengan mengacu pada pandangan Abu Hanifah yang berbeda dengan pendapat jumhur ulama. Hasybi bependapat bahwa mesin-mesin produksi di pabrik besar wajib di zakati. Pandangan ini cukup relevan dengan konteks pembangun negara yang membutuhkan banyak modal. Pendapat Hasbi mengenai zakat diserahkan kepada pemerintah untuk mengelolanya. Sebab, bagi Hasbi zakat tersebut sepaket dengan pengebangan untuk kemakmuran masyarakat, baik non muslim maupun muslim. Oleh karena itu, pungutan zakat seharusnya juga tidak hanya ditujukan kepada kaum muslimin, akan tetapi juga kepada kaum nonmuslim. Kemudian, prinsip zakat, yaitu diambil pada jenis harta yang berkembang, harta yang sudah cukup nishabnya, dan zakat harta.
\end{abstract}

Kata Kunci: Pemikiran, Hasybi Ash-Shiddiqy, Ijtihadi Fiqh Zakat 


\section{PENDAHULUAN}

Allah SWT menurunkan syari at (Hukum) Islam untuk mengatur kehidupan manusia, baik selaku pribadi maupun selaku anggota masyarakat.Hal ini berbeda dengan konsep hukum di luar Islam yang hanya ditujukan untuk mengatur kehidupan manusia selaku anggota masyarakat. ${ }^{1}$

Hukum Islam mengalami kemajuan dan perkembangan seiring dengan perkembangan agama Islam ke seluruh dunia. Hal ini membawa banyak perubahan dan kebutuhan umat Islam akan adanya penyelesaian-penyelesaian masalah yang berkembang. Perkembangan zaman dan tempat mempengaruhi hukum-hukum Islam. Banyaknya tokohtokoh Islam pembaharu dan modernis mewarnai perkembangan pemikiran modern hukum Islam di dunia dan bahkan di Indonesia. Di Indonesia banyak juga muncul tokoh-tokoh pembaharu yang mempunyai gagasan-gagasan segar dan modern dalam hukum Islam. Salah satunya yaitu Muhammad Hasbi Ash-Shiddieqy seorang tokoh Islam yang lahir di tanah aceh. Oleh karena itu, dalam makalah ini penulis akan membahas pemikiran hukum Islam Muhammad Hasbi Ash-Shiddieqy mulai dari biografi, karyakarya, serta pemikiranpemikiran hukum Islam yang yang terkait dengan ijtihad zakat yang beliau gagas.

Penelitian ini menggunakan pendekatan kualitatif yang digunakan oleh penulis. Sebab dengan metode tersebut bersifat pleksibel, sesuai untuk menganalisa suatu kajian syariah. Menggunakan metode kualitatif juga sangat cocok untuk mengkaji lebih dalam terkait dengan pengelolaan zakat pada pemerintahan Islam mulai pada zaman dahulu sampai saat ini. Kemudian digunakan untuk menganalisa penerapan data-data terhadap perkembangan zakat pada negara yang mengelola zakat. Penelitian mengambil ruang lingkup tentang pengelolaan zakat di Indonesia dalam pemikiran Hasbi Ash-Siddiqy. Tujuannya untuk mewujudkan pengelolaan zakat baik dengan menggunakan hukum Islam dan hukum adat yang berlaku di Indonesia.

\section{PEMBAHASAN}

\section{Biografi Teungku Muhammad Hasybi Ash Shiddieqy}

Muhammad Hasybi ash-Shiddieqy dilahirkan di Lhokseumawe Aceh, pada 10 Maret 1904 di tengah-tengah keluarga ulama pejabat, ibunya bernama Tengku Amrah, adalah putri Tengku Abdul Aziz, pemangku jabatan Qadhi Chik Maharaja Mangkubumi. Ayahnya

\footnotetext{
${ }^{1}$ Suparman Usman, Hukum Islam (Asas-asas pengantar studi hukum Islam dalam tata hukum Indonesia) (Cet. II Jakarta: Gaya Media Pratama, 2002), 65.
} 
bernama al-Haj Tengku Muhammad Husen Ibn Muhammad Su'ud menempati jabatan sebagai Qadhi Chik, mereka termasuk golongan orang-orang besar Tengku Chik di Simeuluk Simalangga. ${ }^{2}$ Tengku Chik di Simeuluk adalah keturunan Faqir Muhammad (Muhammad Al-Ma'shum) ialah adalah keturunan Abu Bakar ash-Shiddiq, Khalifah pertama dari deretan Khalifah Al-Rasyidin, bahkan ada beberapa tulisan yang mengatakan bahwa Hasybi adalah keturunan ke-30 dari Abu Bakar Shiddiq. Terkait dengan hal tersebut semua anggota keluarganya diberikan sebutan nama Ash Shiddiqy dibelakang namanya, bermula pada tahun $1925 .^{3}$

Ketika remaja ia telah dikenal dikalangan masyarakat karena ia sudah terjun berdakwah dan berdebat dalam diskusi-diskusi, sehingga mereka terkenal dan menjadi populer dikalangan masyarakat pada saat itu. ${ }^{4}$ Jenjang pendidikan pertamanya adalah di Pesantren yang dipimpin oleh ayahnya . Pada usia 8 tahun ia telah khatam Al-Qur'an dan satu tahun ia belajar Qira'ah dan Tajwid serta dasar-dasar Tafsir dan Fiqh kepada ayahnya. Setelah belajar dengan ayahnya ia kemudian bertemu dengan salah satu pemikir pembaharu dalam Islam di Indonesia, yaitu Syekh Muhammad Ibn Salim al-Kalali, ia bertempat tinggal di Lhokseumawe. Pertemuan Hasbi dengan Syekh al-Kalili ia mendapat kesempatan untuk membaca kitab-kitab yang ditulis oleh pelopor-pelopor kaum pembaharu pemikiran Islam dan juga berkesempatan membaca majalah-majalah yang menyuarakan suara-suara pembaharuan yang diterbitkan di Singapura, pulau Pinang dan Padang dan juga mendapat bimbingan langsung dari Syekh al-Kalili. ${ }^{5}$

Hasybi juga terjun didunia pendidikan dan membangun sarana pendidikan serta menulis beberapa karya. Beliau wafat dirumah sakit Islam Jakarta pada hari selasa tanggal 9 Desember 1975, tepat sepekan mendahului Prof. Dr. Hazairin. Ia dimakamkan berdampingan dengan makam Prof. Thoha Yahya Omar dan dekat makam Sa'aduddin Jambek di pemakaman IAIN Syari Hidayatullah Jakarta Ciputat Jakarta Selatan. Hasybi wafat dengan meninggalkan 4 orang anak (2 laki-laki dan 2 perempuan) dan tujuh belas cucu.

Muhammad Hasybi Ash-Shiddieqy lahir di lhokseumawe, aceh utara 10 Maret 1904 di tengah keluarga ulama pejabat. Dalam tubuhnya mengalir darah campuran arab dari

\footnotetext{
${ }^{2}$ Nouruzzaman Shiddieqy. Fiqh Indonesia, Penggagas dan Gagasannya. (Cet. ke-1 Yogyakarta: Pustaka Pelajar, 2001), 3.

${ }^{3}$ Ensiklopedi Islam. (Cet. Ke-VI jilid-2, Jakarta: PT. Ichtra Van Hoeve, 1999), 94.

${ }^{4}$ Nourouzzaman Shiddiqi, Fiqih Indonesia, Pustaka Pelajar, Yogyakarta, 1997, 10.

${ }^{5}$ Ensiklopedi Islam, 94.
} 
silsilahnya diketahui bahwa beliau keturunan ke-37 dari Abu Bakar ash-Shiddieq. Anak dari pasangan Teungku Amrah, puteri Teungku Abd al-Aziz pemangku jabatan Qadhi Chik Maharaja mangkubumi dan Al-Hajj Teungku Muhammad Husen ibn Muhammad Maseeud. Ketika berusia 6 tahun ibunya wafat dan diasuh oleh Teungku Syamsiyah (bibinya). Sejak berusia 8 tahun Hasbi meudagang (nyantri) dari dayah satu ke dayah yang lain yang berada di pusat kerajaan Pasai tempo dulu.

Sisi menarik Muhammad Hasbi adalah, Pertama, ia seorang otodidak. Pendidikan yang ditempuhnya dari dayah ke dayah dan hanya satu setengah tahun duduk di bangku sekolah Al-Irsyad (1926). Basis pendidikan formal seperti itu, ia memperlihatkan dirinya sebagai seorang pemikir. Kemampuannya selaku seorang intelektual diakui oleh dunia internasional. Ia diundang dan menyampaikan makalah dalam international colloquium yang diselenggarakan di lahore Pakistan (1958). Diluar hal tersebut, ia memiliki perbedaan dengan tokoh-tokoh pembaharu lainnya di Indonesia, sebab sebelum beliau naik haji mereka sudah menyampaikan pembaharuan di Timur Tengah pada saat menempuh pendidikan. Kedua, ia mulai bergerak di aceh, di lingkungan masyarakat yang dikenal fanatic, bahkan ada yang menyangka “angker”. Namun, Hasbi pada saat pertama kali menempu perjuangan pembeharuan ia sangat berani perbedaan, ia sangat kuat kuat keyakinannya dan semangat yang tinggi untuk melakukan perjuangan pembaharuan meskipun ia dimusuhi oleh mereka yang tidak sepaham dengannya. Ketiga, dalam berpendapat ia merasa dirinya bebas tidak terikat dengan penapat kelompoknya. Bahkan ia berani berbeda pendapat dengan jumhur ulama, sesuatu yang langka terjadi di Indonesia. Keempat, ia adalah orang pertama di Indonesia yang sejak tahun 1940 dan dipertegas lagi pada tahun 1960, menghimbau perunya dibina fiqih yang berkepribadian Indonesia. Himbauan ini menyentak sebagian ulama Indonesia.Mereka angkat bicara menentang fiqih (hukum in concrete) di-indonesia-kan atau dilokalkan. Bagi mereka, fiqih dan syariat (hukum in abstracto) adalah semakna dan samasama universal.

Karir akademiknya, menjelang wafat, memperoleh dua gelar Doctor Honoris Causa karena jasa-jasanya terhadap perkembangan perguruan tinggi Ilsam dan perkembangan ilmu pengetahuan ke-Islaman di Indonesia. Satu diperoleh dari universitas Islam bandung (UNISBA) pada tanggal 22 Maret 1975 dan dari IAIN Sunan Kalijaga Yogyakarta pada tanggal 29 Oktober 1975. Tanggal 9 Desember 1975, setelah beberapa hari memasuki karantina haji, dalam rangka menunaikan ibadah haji, beliau wafat, dan jasad beliau 
dimakamkan di pemakaman keluarga IAIN Ciputat Jakarta. Pada upacara pemakaman pelepasan jenazah almarhum, turut memberi sambutan almarhum Buya Hamka dan pada saat pemakaman beliau dilepas oleh almarhum Mr. Moh. Rum. Naskah terakhir yang diselesaikan adalah pedoman Haji. ${ }^{6}$

\section{Karya Intelektual Hasbi}

Hasybi adalah ulama yang produktif menuliskan idea pemikiran keislaman. Menurut catatan, buku yang ditulisnya berjumlah 73 judul (142 jilid). Sebagian besar karyanya adalah bidang fikih (36 judul). Bidang-bidang lainnya adalah hadis (8 judul), tafsir (6 judul), tauhid (ilmu kalam) (5 judul). Sedangkan selebihnya tidak kurang 17 judul adalah tema-tema keislaman yang bersifat umum dan tidak kurang 50 artikel telah ditulisnya dalam bidang tafsir, hadis, fikih dan ushul fikih serta pedoman ibadah. Di antara karya-karya tersebut, berikut ini hanya akan dikemukakan beberapa karya yang terkait dalam bidang-bidang ilmu tertentu.

Bidang Tafsir dan ilmu Al Quran: (1) Beberapa Rangkaian Ayat (1952); (2) Sejarah dan Pengantar Ilmu Tafsir (1954); (3) Tafsir Al-Qur'anul Majid An-Nur (30 juz) (1956); (4) Tafsir Al Bayan (1966); (5) Mujizat al-Quran (1966); (6) Ilmu Ilmu al-Quran: Media Pokok dalam Menafsirkan al-Quran (1972).

Bidang Hadis dan Ilmu Hadis : (1) Beberapa Rangkuman Hadis (1952); (2) Sejarah dan Pengantar Ilmu Hadis (1954); (3) 2002 Mutiara Hadist, 8 jilid (1954-1980); (4) PokokPokok Ilmu Dirayah Hadis, 2 jilid (1958); (5) Problematika Hadis sebagai Dasar Pembinaan Hukum Islam (1964); (6) Koleksi Hadis-hadis Hukum, 11 jilid (1970-1976); (7) Rijalul Hadis (1970); (8) Sejarah Perkembangan Hadis (1973).

Bidang Fikih/Ushul Fikih: (1) Sejarah Peradilan Islam (1950); (2) Tuntunan Qurban (1950); (3) Pedoman Shalat; (4) Hukum-hukum Fiqih Islam; (5) Pengantar Hukum Islam (1953); (6) Pedoman Zakat; (7) Al-Ahkam (Pedoman Muslimin) (1953); (8) Pedoman Puasa; (9) Kuliah ibadah; (10) Pemindahan Darah (Blood Transfusion) Dipandang dari Sudut Hukum Islam (1954); (11) Ichtisar Tuntunan Zakat dan Fitrah (1958); (12) Syariat Islam Menjawab Tantangan Zaman (1961); (13) Peradilan dan Hukum Acara Islam; (14) Poligami Menurut Syariat Islam (15) Pengantar Ilmu Fiqih (1967); (16) Baitul Mal Sumbersumber dan Penggunaan Keuangan Negara Menurut Ajaran Islam (1968); (17) Zakat Sebagai Salah Satu Unsur Pembina Masyarakat Sejahtera (1969); (18) Asas-asas Hukum

${ }^{6}$ Nourouzzaman Shiddiqi, Fiqih Indonesia (Yogyakarta: Pustaka Pelajar, 1997), 3. 
Tatanegara Menurut Syariat Islam (1969); (19) Sejarah Pertumbuhan dan Perkembangan Hukum Islam (1971). (20) Hukum Antar Golongan dalam Fikih Islam; (21) Perbedaan Mathla' Tidak Mengharuskan Kita Berlainan pada Memulai Puasa (1971); (22) Ushul Fikih; (23) Ilmu Kenegaraan dalam Fikih Islam (1971); (24) Beberapa Problematika Hukum Islam (1972); (25) Kumpulan Soal Jawab (1973) (26) Pidana Mati dalam Syari'at Islam; (27) Sebab-sebab Perbedaan Faham Para Ulama dalam Menetapkan Hukum Islam; (28) Pokokpokok Pegangan Imam-imam Madzhab dalam Membina Hukum Islam; (29) Pengantar Fiqih Muamalah; (30) Fakta-fakta Keagunagan syariat Islam (1974); (31) Falsafah Hukum Islam (1975); (32) Fikih Islam Mempunyai Daya Elastis, Lengkap, Bulat dan Tuntas (1975); (33) Pengantar Ilmu Perbandingan Madzhab (1975); (34) Ruang LIngkup Ijtihad Para Ulama dalam Membina Hukum Islam (1975); (35) Dinamika dan Elastisitas Hukum Islam (1976); (36) Pedoman Haji. ${ }^{7}$

\section{Hakikat Zakat Menurut Hasbi Ash-Shiddiqy}

Hakikat zakat secara bahasa (etimologi) zakat ialah bersih tumbuh, berkembang, berkah, pujian, dan kebaikan. ${ }^{8}$ Zakat secara etimologi terdapat juga penjelasan dalam QS At-Taubah/9:103.

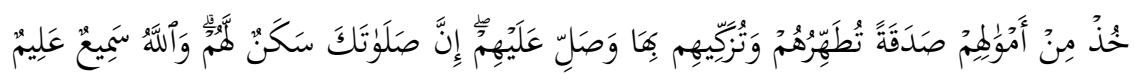

"Ambillah zakat dari harta mereka guna membersihkan dan menyucikan mereka dan berdoalah untuk mereka. Sesungguhnya doamu itu (menumbuhkan) ketenteraman jiwa bagi mereka. Allah Maha mendengar dan Maha mengetahui". 9

Berdasarkan penjelasan ayat tersebut menegaskan bahwa zakat merupakan pembersih dan pensuci untuk bagi diri sendiri. Oleh karena itu, orang yang mengeluarkan zakat akan mendapatkan ketenangan jiwa serta wajah mereka bersinar dengan kebersihannya.

Mengeluarkan zakat merupakan bentuk gerakan untuk mewujudkan sikap keadilan dalam masyarakat. Perbuatan yang adil akan berdampak pada kehidupan yang menjunjung tinggi nilai-nilai kebaikan. ${ }^{10}$ Hakikat mengeluarkan zakat tidak hanya untuk kesuburan harta

\footnotetext{
${ }^{7}$ Aan Supian, Kontribusi Pemikiran Hasbi Ash-Shiddieqy Dalam Bidang Fikih (Media Syariah, Vol. XIV No. 2 Juli - Desember 2012), 19-192.

${ }^{8}$ Gustian Djuanda, dkk, Laporan Zakat Pengurangan Pajak Penghasilan, (Jakarta, PT Raja Grafindo Persada, 2006), 10.

${ }^{9}$ Iqbal Ambara, Problematika Zakat dan Pajak di Indonesia, Cet Ke-1 (tt: Sketsa, 2009), 19.

${ }^{10}$ Abdurrachman Qadir, Zakat Dalam Dimensi Mahdhah dan Sosial (Jakarta: PT Raja Grafindo Persada, 2001), 57.
} 
bagi diri sendiri, akan tetapi untuk memakmurkan juga masyarakat agar hidup sejahterah. Begitu juga zakat yang dikeluarkan untuk memberikan bantuan kepada masyarakat yang miskin, lemah baik secara fisik maupun mental. ${ }^{11}$

Terkait dengan hal itu mengeluarkan zakat merupakan pensuci harta dan jiwa seseorang untuk mendapatkan ketenangan hidup, serta untuk membantu masyarakat yang miskin dan lemah untuk mendapatkan kehidupan yang sejahterah. Menurut pendapat empat Madzab yang menjadi pedoman umat Islam dalam menentukan hukum syara', ia memaknai zakat dengan pendapat yang berbeda-beda. Pendapat para penganut keempat mazhab tersebut yaitu:

1. Madzhab Syafi'i; Zakat ialah sebuah ungkapan untuk mengeluarkan harta atau tumbuh sesuai dengan cara yang khusus.

2. Madzhab Maliki; Zakat ialah mengeluarkan sebagian yang khusus dari harta yang khusus pula yang telah mencapai nishab kepada orang-orang yang berhak menerimanya. Manakala kepemilikan itu penuh dan sudah mencapai haul (satu tahun).

3. Madzhab Hanafi; Zakat ialah mnejadikan sebagian dari harta yang khusus sebagai milik orang yang khusus sesuai ketentuan syarieeat.

4. Madzhab Hambali; Zakat ialah hak wajib dikeluarkan dari harta yang khusus untuk kelompok yang khusus pula. ${ }^{12}$

Para ulama memberikan pandangan yang berbeda dalam memaknai zakat, akan tetapi, pada hakikatnya memiliki tujuan yang sama dengan yang lainnya. Zakat menurut kesepakatan para ulama merupakan mengeluarkan sebagian harta sesuai dengan ketentuan syar'i yang telah ditentukan. Pemilik harta tersebut diwajibkan oleh Allah swt, untuk dikeluarkan zakatnya, kemudian diberikan kepada orang yang kurang mampu dan berhak menerimanya.

Oleh karena itu, Hasbi Ash-Shiddiqy (1999) berpendapat bahwa zakat adalah pengambilan tertentu dari harta yang tertentu, menurut sifat-sifat yang tertentu untuk diberikan kepada golongan yang tertentu. ${ }^{13}$

Maksud pernyataan Hasbi tersebut adalah harta dapat yang dikeluarkan zakatnya apabila telah sampai pada perhitungan (nishab) kekayaan yang dimiliki oleh seseorang,

\footnotetext{
${ }^{11}$ Muhammad Hasbi ash-Shiddieqy, Pedoman Zakat, (Cet.ke-1, Edisi ke-3, Semarang: Pustaka Rizki Putra, 2009, 6-7.

${ }^{12}$ Iqbal Ambarawa, Problematika Zakat dan Pajak di Indonesia, 20.

${ }^{13}$ Tengku Muhammad Hasbi Ash Shiddiqy, Pedoman Zakat, (Semarang: Pustaka Rizki Putra, 2009), 43.
} 
kemudian harta tersebut dikeluarkan sesuai sifat dan jenis harta yang dimiliki. Zakat tersebut yang dikeluarkan diserahkan kepada yang berhak menerimanya, dengan kata lain diberikan kepada orang miskin atau kurang mampu dan orang lemah baik secra fisik maupun mental.

\section{Sumber Ijtihad Hasybi Ash-Sidiqqy}

1. Al-Qur'an

Berkaitan dengan sumber Hukum Islam, Hasybi mempunyai beberapa pandangan tentang eksistensi al-Qur'an sebagai sumber Hukum Islam, yakni: Pertama, Masalah penerjemahan dan penulisan al-Qur'an ke dalam bahasa dan aksara selain Arab, Kedua, Masalah Nasikh dan Mansukh dalam al-Qur'an, Ketiga, Metode penafsiran, dan Keempat, Tentang cerita Israiliyyat yang dipakai oleh sebagian Mufassir. Dalam masalah penerjemahan dan penafsiran al- Qur'an ke dalam bahasa dan aksara selain Arab, Hasybi memilih pendapat yang membolehkan seperti yang dianut oleh sebagian Ulama Mesir, India, dan Syatibi. Dalam masalah ini Hasybi tidak sepakat dengan Ibn Taymiyyah yang dipertahankan oleh Rasyid Ridha dalam majalah al-Mannar dan dinukilkan kembali dalam Tafsir al-Mannar dan dipegang teguh oleh Abd. Rahman Taj. Alasan mereka, tidak mungkin bahasa al-Qur'an dapat disalin ke dalam bahasa lain dengan makna yang tepat. ${ }^{14}$

Menurut Hasybi, dalam beberapa tempat al-Qur'an menamakan dirinya dengan Zikru li al- 'Alamin dan Muhammad diutus untuk menjadi Naziru li al- 'Alamin. Agar alQur'an dapat mengfungsikan dirinya menjadi Zikru li al-'alamin, maka penerjemahan alQur'an ke dalam bahasa-bahasa dunia tentulah suatu cara yang menunjang tercapainya fungsi al-Qur'an, karena ituselayaknya tidak dilarang, kalaupun tidak mau menggalakkannya. ${ }^{15}$ Tentang penggunaan huruf selain huruf Arab untuk menulis alQur'an, ia membolehkannya. Sikap Hasybi tersebut dibarengi dengan beliau langsung menyusun Tafsir al-Qur'an Majied "an-Nuru” 30 jilid dan tafsir al-Bayan 4 jilid dalam bahasa Indonesia. Untuk menafsirkan ayat per ayat, dalam tafsir an-Nur, ia menggunakan aksara latin untuk menulis ayat. Mengenai Nasikh-Mansukh dalam al-Qur'an ia berpendapat bahwa al-Qur'an tidak mengandung ayat-ayat yang nasikh dan mansukh. Ia memilih pendapat ini, disamping pendapat ini baginya yang lebih benar, juga ia melihat pihak yang berpendapat ada ayat nasikhmansukh, tidak pula ada kata sepakat tentang berapa jumlah ayat-ayat tersebut. Maka kepastian tentang berapa ayat yang nasikh dan

${ }^{14} 5$ Shiddieqy. Fiqh Indonesia, 106-107.

${ }^{15}$ Hasybi ash-Shiddieqy. Mu'djizat al-Qur'an (Jakarta: Bulan Bintang, 1994), 49-50. 
mansukh berarti menetapkan bahwa di dalam al-Qur'an ada yang batal atau salah. AlQur'an adalah syari'at yang diabadikan hingga kiamat dan menjadi hujjah sepanjang masa. Dalam posisi al-Qur'an seperti ini, tidak patut jika di dalamnya ada ayat-ayat yang tidak berlaku lagi. Apalagi harus diingat pula, kebanyakan kandungan al-Qur'an bersifat Kulliyat bukan juz'I khas, hukum-hukum di dalamnya diterangkan secara ijmali, bukan tafsili. Arti Nasakh yang sebenarnya ialah menukilkan. Jikapun nasakh hendak diartikan dengan penghapusan hukum dan ayat ialah ayat al-Qur'an, maka pemahamannya ialah boleh jadi nasakh, jadi bukan terjadi nasakh dalam al-Qur'an. Berdasarkan dengan perbedaan makna antara ayat yang satu sama lainnya yang terdapat dalam Al-Qur'an baik secara lahiriyah maupun penafsirannya, maka dapat diselesaikan dengan cara menakwilkan makna ayat-ayat tersebut sehingga konradiksinya dapat dihilangkan. ${ }^{16}$

Tentang metode penafsiran, Hasybi berpendapat bahwa dalam menafsirkan alQur'an pertama kali harus dicari penjelasannya pada al-Qur'an sendiri. Oleh sebab itu, sering sekali didapatkan ada kutipan ayat yang disebutkan secara ringkas disuatu tempat, sedangkan penjelasan ayat tersebut berada di tempat lain. Dikarenakan Allah lebih mengetahui kehendaknya. Jika tidak ditemukan ayat yang menjadi penjelas bagi suatu yang hendak ditafsirkan, barulah dicari penjelasannya pada Hadis, jika tidak terdapat pada Hadis, barulah melihat pada penafsiran Sahabat. Adapun cerita-cerita Israiliyat dan Nashraniyat yang sebagian ulama Tabi'in digunakan untuk menafsirkan ayat-ayat alQur'an, Hasybi menyesali sikap lengah mereka. Oleh karena itu, sikap toleransi ini tidak disepakati oleh sebagian ulama dan tidak setujui oleh Hasybi.

2. Al-Sunnah

Al-Sunnah merupakan sumber hukum kedua setelah Al-Qur'an ynag telah disepakati oleh para jumhur ulama bidang hukum Islam. Hasybi berpandangan bahwa pendapat ahli ushul fiqh yang mesti dipahami serta diperaktikkan, yaitu sunnah adalah segala perkataan, perbuatan/ ucapan, taqrir Nabi yang berkaitan dengan hukum. Ia mengatakan bahwa menurut ahli Hadis, pengertian Hadis dan Sunnah mengandung makna yang sama. Akan tetapi, pada hakikatnya ada perbedaan antara Hadis dengan Sunnah. ${ }^{17}$ Oleh karena itu, jika dilihat pada makna lafal penukilannya tidak mutawatir

\footnotetext{
${ }^{16}$ Hasybi, Sejarah dan Pengantar Ilmu Al-Qur'an/Tafsir (Cet.ke-Vll, Jakarta: Bulan Bintang, 1980), $122-125$

${ }^{17}$ Hadis ialah semua peristiwa yang disandarkan pada Nabi, walaupun hanya sekali saja terjadi di sepanjang hayatnya. Adapun Sunnah adalah amaliyah Nabi yang mutawatir, khususnya dari segi maknanya.
} 
yang mengakibatkan sanadnya menjadi tidak mutawatir juga, akan tetapi, dalam penggunaannya mutawatir, maka bisa dikatakan sunnah. ${ }^{18}$

Menurutnya, Sunnah sebagaimana halnya al-Qur'an, mempunyai dua sifat: pertama, penetapannya hukum; kedua, pedoman untuk menetapkan suatu hukum. Penetapan hukum yang diberikan Nabi tidak pernah berlawanan dengan asas-asas yang dianut al-Qur'an. Oleh sebab itu dalam penentuan hukum yang dicontohkan Nabi memiliki ciri-ciri umum dan khusus. ${ }^{19}$ Ciri-ciri yang menjadi petunjuk untuk membuktikan yang termasuk hadis umum atau khusus adalah terletak pada keterangan (qarinah) yang menyebutkan kekhususannya atau keumumannya. Jika terhadap alQur'an Hasybi memilih pendapat yang menyatakan tidak ada nasikh dam mansukh terhadap hadis khususnya Hadis Qauli da mengambil pendapat yang menyatakan ada nasikh dan mansukh, pemansukhan suatu Hadis ada yang dilakukan oleh al-Qur'an dan ada juga yang dilakukan oleh Hadis yang datang kemudian. ${ }^{20}$ Terkait pembatasan hadis yang mengkut masalah hukum, Hasbi berpendapat bahwa hadis shahih adalah hadis yang tidak memiliki cacat pada susunan matannya, tidak bertolak belakang dengan Al-Qur'an atau khabar mutawatir dan mata rantai sanadnya adalah orang-orang yang adil dan kuat hafalannya. Namun, pada hakikatnya hadis bisa dikatakan hadis shahih apabila tidak terkandung cacat baik pada sanad, matan, dan tidak bertolak belakang dengan ayat AlQur'an. Oleh karena itu, menurut Hasybi yang hanya Shahih pada sanadnya saja belum termasuk kategori Hadis Shahih. ${ }^{21}$ Terkait dengan hadis ahad, Hasybi memiliki pendapat yang sama dengan Syafi'i yang mengatakan bahwa hadis ahad tidak digunakan untuk menghkhususkan (takhsis) hakikat yang bersifat global yang disebutkan dalam AlQur'an, melainkan kandungan hadis ahad telah disepakati oleh para ulama. ${ }^{22}$

Adapun Hadis dhaif, Hasybi mengatakan, seluruh ulama sepakat tidak membolehkan digunakan Hadis dhaif untuk menetapkan suatu hukum. Orang yang meriwayatkan Hadis dhaif dilarang menyebutkan dengan tegas, bahwa Nabi bersabda. ${ }^{23}$

\footnotetext{
${ }^{18}$ Hasybi. Sejarah dan Pengantar Ilmu Hadis (Cet Ke-6, Jakarta: Bulan Bintang, 1974), 22.

${ }^{19}$ Lihat Ciri umum berlaku untuk semua bangsa dan tempat serta waktu. Sedangkan yang khusus hanya berlaku untuk masyarakat dalam waktu tertentu.

${ }^{20}$ Shiddieqy. Fiqh Indonesia, 112.

${ }^{21}$ Hasybi, Pokok-pokok Ilmu Dirayah Hadis. (Cet. Ke-5, jilid 1, Jakarta: Bulan Bintang, 1981), 109.

${ }^{22}$ Hasybi, Pokok-pokok Ilmu Dirayah Hadis, 66.

${ }^{23}$ Hasybi, Pokok-pokok Ilmu Dirayah Hadis, 239.
} 
3. 'Urf

Tentang 'urf tampaknya Hasybi mempunyai perhatian yang khusus. Menurut hasbi hukum fiqh yang seharusnya diberlakukan di Indonesia adalah fiqh yang sesuai versi Indonesia. ${ }^{24}$ Terkait dengan dasar hukum fiqh versi Indonesia akan menjadi suatu pengalaman yang mengandung pengertian 'urf yang sesuai dengan ketentuan hukum syar'i yang berlaku dalam Islam. Kata 'urf sangat berpengaruh besar dalam memperkaya khazanah hokum fiqh di Indonesia. Akan tetapi, hukum 'urf diberlakukan berdasarkan penilaian oleh hukum syara' yang menjadi tolak ukur dalam penggunaan 'urf tersebut.

4. Prinsip mengubah hukum sesuai dengan perkembangan

Di samping prinsip 'urf dan adat istiadat yaitu prinsip yangn menghasilkan daya elastis bagi hukum Islam, ada lagi suatu prinsip yaitu prinsip mengubah hukum sesuai dengan perkembangan masa, tempat dan kebutuhan. Prinsip ini tidak terlalu diperhatikan oleh ulama Ushul. Prinsip ini, lanjut Hasybi, mengharuskan kita memperhatikan kemaslahatan masyarakat dan kemaslahatan yang menjadi dasar bagi hukum. Menurut penelitian yang dilakukan oleh para ahli, apabila suatu nash berpautan dengan urusan ibadah, maka nash itu tetap berjalan terus tidak berubah dan tidak dapat diganti-ganti. Dan apabila nash itu berpautan dengan urusan mu'amalat, maka yang diperhatikan dalam hal ini, ialah pengertian-pengertian yang dimaksudkan daripada hukum dan illat-illatnya. Para ulama berbeda pendapat dalam merubah hukum yang telah ditetapkan nash, dan yang menidakbolehkan dan ada yang membolehkan dalam sebahagian keadaan. ${ }^{25}$ Ketika Hasybi berbicara tentang ungkapan fuqaha mengubah hukum karena zaman berubah, ia banyak menampilkan terobosan hukum yang pernah dilakukan Umar bin Khattab, meskipun terobosan yang dilakukannya itu atas nama siyasat syar'iyyah, yakni hukumhukum fiqh yang diwujudkan untuk memelihara maqasid syar'iyyah. Menurut Hasybi, hukum yang ditetapkan berdasarkan maqasid syar'iyyah bukan hukum yang bersifat umum dan tetap, melainkan ia sebagai hukum yang berkembang, dinamis sesuai dengan perkembangan zaman, berubah-ubah dan berganti-ganti. ${ }^{26}$

\footnotetext{
${ }^{24}$ Tentang fiqh yang berkepribadian Indonesia ini senada dengan yang dilontarkan oleh Prof. K. Ali Yafie dalam seminar tentang Bedah Pemikiran Hasybi; Relevansi gagasan fiqh Indonesia dalam Wacana Formalisasi Syari'ah Islam. Lanjutnya, Hasybi sendiri tidak pernah menngatakan Fiqh Indonesia, tapi fiqh berkepribadian Indonesia.

${ }^{25}$ Hasybi, Dinamika dan Elastisitas Hukum Islam (Jakarta: Tintamas, 1975), 34-35.

${ }^{26}$ Hasybi, Kumpulan Soal-Jawab (Cet. ke-1Jakarta: Bulan Bintang, 1973), 61.
} 
5. Maslahat Mursalah

Tidaklah ada perselisihan pendapat antara para ulama bahwa segala hukum syara' dimaksudkan untuk mewujudkan kemaslahatan manusia, baik yang dlaruriyah, hajiyat, maupun tahshiniyat. Dengan kita memperhatikan pendapat-pendapat ulama mengenai maslahat mursalah nyatalah bahwa tak ada seorangpun yang mengatakan bahwa syari'at tidak dibina atas dasar maslahat. ${ }^{27}$

\section{Prinsip-Prinsip dalam Pelaksanaan Zakat Menurut Hasbi Ash-Shiddiqy}

Berdasarkan pendapat hasbi terkait dengan masalah zakat ia sependapat jumhur ulama bahwa yang menjadi pokok zakat adalah harta bukan orang. Setiap orang berhak mengeluarkan zakat harta yang mereka miliki tanpa mengenal agama yang mereka anut. Oleh sebab itu, Hasbi berpendapat bahwa zakat dapat juga dipungut melalui non muslim untuk mempertimbankan sebagai upaya pemerintah dalam memakmurkan serta untuk menjamin kesejahterahkan rakyat. Pemikiran Hasbi tersebut ia berdasarkan pada pendapatnya, yaitu; Pertama, zakat hukumnya boleh digunakan untuk semua agama. Kedua, Umar ibn al-Khaththab (581-644 M.), pernah memutuskan untuk memungut zakat melalui kaum Nasrani Bani Taghluba, pada saat itu ia menjabat sebagai khalifah kedua setelah meninggalnya Nabi Muhammad Saw. ${ }^{28}$ Pembagian zakat kepada masyarakat disalurkan pada penduduk yang kurang mampu atau miskin, baik dikalangan muslim maupun non muslim karena mereka juga mendapat hak untuk menerima bagian zakat. Pendapat tersebut betujuan untuk upaya membangun kemakmuran penduduk yang terdapat pada satu negara. Pandangannya ini didasarkan pada fungsi zakat sebagai upaya membina kesejahteraan masyarakat dalam satu negara. Secara Umum zakat yang dikeluarkan tersebut berfungsi agar dapat menjadikan masyarakat untuk hidup dengan jiwa yang bersih, jujur, adil, serta menjungjung tinggi nilai-nilai sosial, sehingga dapat mewujudkan cita-cita pemerintah untuk menjadi negara yang makmur dan sejahterah. Berdasarkan pada pendapat Hasbi terkait dengan pemberian zakat atau penerima zakat adalah non-muslim itu tidak masalah dengan maksud untuk menegakkan keadilan dan kesejahteraan masyarakat. Sejalan dengan pendapat aliran Mazhab Hanafi dan Maliki, ia tidak melarang berzakat kepada non-muslim

\footnotetext{
${ }^{27}$ Hasybi, Dinamika dan Elastisitas Hukum Islam (Jakarta: Tintamas, 1975), 34.

${ }^{28}$ Muhammad Hasbi Ash-Shiddieqy, Pedoman Zakat, (Semarang: Pustaka Rizki Putra, 2009), 58
} 
karena dengan alasan keumuman kata fakir dan miskin. Jadi siapapun boleh menerima zakat baik orang muslim maupun orang orang non-muslim memiliki hak yang sama. ${ }^{29}$

Terkait dengan pemahaman dikalangan orang muslim mengenai zakat dalam rukun Islam merupakan suatu hal yang wajib dan tidak dapat dipisahkan pada keislaman orang tersebut. Sudah diatur secara mutlak dalam hukum syar'i terkait mengenai nishab (batasan harta yang harus dikeluarkan zakatnya), kadar zakat yang wajib dikeluarkan, syarat-syarat, waktu, dan cara pembayarannya. Pelaksanaan dapat dibagi menjadi tiga kelompok, yaitu; 1) yang membayar zakat (muzakki), 2) yang menerima zakat (mustahid), 3) yang menyalurkan zakat (amilin), yaitu orang yang ditugaskan oleh pemerintah setempat.

Zakat yang dikelola dengan baik akan memperoleh pengaruh terhadap kemakmuran dan kesejahteraan penduduk dalam satu negara atau daerah. Pengumpulan zakat yang didapatkan melalui harta kekayaan yang ada dalam masyarakat dapat dikumpulkan, kemudian disalurkan kepada fakir miskin atau masyarakat yang kurang mampu di daerah tersebut. $^{30}$

Berdasarkan pada penjelasan tersebut maka Hasybi berpendapat sebagaimana yang dikutip dalam buku karangannya yang berjudul; Fiqh Indonesia, Penggagas dan Gagasannya (1997), ia berpandangan bahwa terdapat tiga prinsip dasar dalam pelaksanaan zakat, yaitu:

1. Jenis zakat dapat diambil dari harta yang berkembang.

2. Zakat dapat diambil setelah mencapai batas kekayaan (nishab) yang telah ditentukan untuk pengeluaran zakat dipungut setelah mencapai nilai batas kaya (nishab). Nishab tersebut telah ditentukan oleh nash syara' maka tidak bisa diubah sesuai dengan kondisinya. Misalnya, harta berupa emas maka tidak bisa diganti dengan lainnya.

3. Zakat harta (zakat al-mal), adalah dikeluarkan setiap tahun.

Terkait dengan hal itu menurut Hasbi Ash Siddiqy berpendapat bahwa secara umum harta yang wajib dikeluarkan zakat adalah berupa harta, yaitu:

1. Harta zahir (amwal zhahiriyah) merupakan harta dapat dihitung meskipun bukan pemilik harta tersebut. Misalnya harta yang berupa harta hasil pertanian seperti biji-bijian, buahbuahan, dan kekayaan hewan ternak seperti sapi, unta, dan kambing. Termasuk dalam harta zahir ialah barang tambang dan rikaz.

\footnotetext{
${ }^{29}$ Rusydi Sulaiman, Zakat dan Keadilan Sosial: Optimalisasi Pengelolaan Zakat Profesi untuk Pemberdayaan Umat, (Asy-Syari'ah: Jurnal Ilmu Syari'ah dan Perbangkan Islam, Vol. 6, No. 2, Desember 2021, pp. 125-144), 138.

${ }^{30}$ Mo Ahyar Maarif. (2019). Baitul Mal pada Masa Rasulullah Saw dan Khulafaur Al-Rasyidin. Asy-Syari'ah : Jurnal Hukum Islam , 5 (2), 137-150.
} 
2. Harta batin (amwal bathiniyah) ialah harta yang berupa emas, perak, uang, serta harta hasil perdagangan dan hasil kerja sebagai buruh dan profesi.

Berdasarkan beberapa jenis harta yang dapat ditentukan dengan berapa besar persen harta yang wajib dikeluarkan. Harta tersebut tidak sama semua besar persennya yang wajib dikeluarkan. Tergantung betapa berat atau sulit dalam memperoleh harta itu, jika harta tersebut diperoleh dengan mudah maka wajib dikeluarkan lebih besar tapi kalau didapatkan dengan sulit dan membutuhkan ongkos dan tenaga yang banyak maka wajib zakatnya lebih kecil juga. Oleh karena itu, dapat dilihat bahwa jenis-jenis harta yang dapat dikeluarkan sesuai dengan kadarnya. Terkait dengan hal maka dapat ditentukan harta yang wajib dikeluarkan sebesar $10 \%$ adalah harta yang diperoleh melalui hasil pertanian yang tidak mebutuhkan pengairan serta ongkos dan tidak menguras tenaga manusia. Kemudian harta yang dapat dikeluarkan sebanyak 5\% adalah harta yang membutuhkan biaya dan ongkos kerja serta menguras tenaga manusia. Begitu juga terdapat jenis harta yang wajib zakatnya hanya $2,5 \%$ yaitu harta berupa emas, perak, harta yang diperjual belikan dan zakatnya hanya dibayar sekali saja. Ada lagi zakat hewan ternak yang diatur amat rapi pengelbegitu juga dengan harta yang lainya dapat ditentukan sesui kadar dari harta tersebut. uaran zakatnya. Ada pula harta yang ditemukan dari dalam bumi, yakni barang tambang, kekayaan laut, atau harta karun yang disebut rikaz, zakatnya $20 \%$, tidak mensyaratkan haul (masa satu tahun) dan dikeluarkan sekali saja pada saat diperoleh setelah dibersihkan. ${ }^{31}$

Petugas zakat (amil) wajib mempunyai pemahaman yanng mendalam terkait dengan harta yang wajib dikeluarkan zakatnya dan tidak wajib dikeluarkan zakatnya. Sebab persoalan zakat juga memerlukan ijtihat atau usaha untuk mencari hukum yang berkembang dikalangan masyarakat. Begitu pula para jumhur ulama memakai metode ijtihad (upaya mencari hukum berdasarkan nash yang ada) dan qiyas untuk menentukan jenis harta yang harus dizakati pada pada zaman sekarang ini. Salah satu sumber zakat yang memiliki peluang atau kemampuan yang banyak untuk pengembangan perekonomian modern yaitu zakat perusahaan. Walaupun sumber hukum mengenai zakat perusahaan tidak terdapat dalam nash Al-Qur'an dan sunnah yang menegaskan secara langsung. Akan tetapi, penetapan zakat perusahaan dapat terlihat pada prinsip zakat yang produktif, biasa dikenal sebagai prinsip an-nama' atau al-istinma (prinsip produktif). Hal tersebut terdapat terlepas

\footnotetext{
${ }^{31}$ http://cilacap.kemenag.go.id/berita/read/dinamika-hukum-zakat, diakses pada 3 Mei 2021
} 
pada kebutuhan pokok berdasarkan dalil-dalil pada umumnya terkait dengan zakat dalam Al-Qur'an dan Sunnah.

Penentuan wajib zakat terhadap jenis-jenis harta yang dimiliki oleh seseorang baik harta yang tumbuh dan berkembang dalam perekonomian modern. Hal tersebut memperlihatkan perkembangan hukum Islam sesuai dengan konteks zaman. Penerapan hukum zakat sangat elastis dalam ekonomi Islam yang meperlihatkan sifat adil dan jiwa yang baik dalam ajaran Islam. Menurut Prof Afif Abdul Fatah Thabbarah Ruh al-Din alIslamy berpendapat bahwa hukum yang terdapat dalam ajaran Islam tidak hanya berkisar pada nilai-nilai keadilan yang berlaku untuk semua ummat manusia. Akan tetapi, berjalan sesuai dengan hukum kemaslahatan serta kebutuhan hidup manusia, sejalan dengan kemaslahatan dan kebutuhan hidup manusia, setiap zaman, dan meskipun zaman itu berubah dan mengalami perkembangan setiap waktu ke waktu.

\section{KESIMPULAN}

Hasbi Ash-Siddiqy berpendapat bahwa zakat adalah harta dapat yang dikeluarkan zakatnya apabila telah sampai pada perhitungan (nishab) kekayaan yang dimiliki oleh seseorang, kemudian harta tersebut dikeluarkan sesuai sifat dan jenis harta yang dimiliki. Zakat tersebut yang dikeluarkan diserahkan kepada yang berhak menerimanya, dengan kata lain diberikan kepada orang miskin atau kurang mampu dan orang lemah baik secara fisik maupun mental. Dasar sumber hukum Islam menurut pendapat Hasbi Ash Siddiqqy berdasar pada, Al-Qur'an, Al-Sunnah, Al-urf, Prinsip mengubah hukum sesuai dengan perkembangan, dan maslahat marsalah. Berdasarkan dengan prinsip dalam pelaksanaan zakat, Hasbi Ash-Siddiqy memberikan sebuah kesimpulan tentang ijtihad fiqh zakatnya, yaitu; 1) Sumber zakat ialah harta yang subur, yang menghasilkan. 2) Mengenai harta kekayaan yang tumbuh pada masa sekarang ini, yang belum dikenal pada masa rasul dapatlah kita melakukan qiyas kepada harta yang telah dikenakan zakat oleh rasul, atau kita keluarkan hukumnya dengan melihat yurisprudensi penetapan para sahabat sesudah rasul wafat. Dengan demikian segala sumber kekayaan yang lahir di zaman modern ini tidak ada yang terlepas dari kewajiban membayar zakat. 3) Zakat tidak terhingga dalam jenis harta yang diambil di masa rasul saja. 


\section{DAFTAR PUSTAKA}

Ambara, Iqbal, Problematika Zakat dan Pajak di Indonesia, Cet Ke-1 ( t.t:Sketsa, 2009).

Djuanda, Gustian, dkk, Laporan Zakat Pengurangan Pajak Penghasilan, (Jakarta, PT Raja Grafindo Persada, 2006).

Ensiklopedi Islam, Cet. Ke-VI jilid-2, Jakarta: PT. Ichtra Van Hoeve, 1999.

Hasybi, Beberapa Permasalahan Zakat (Cet. Ke-1 Jakarta: Tintamas, 1976.

Hasybi, Dinamika dan Elastisitas Hukum Islam, Jakarta: Tintamas, 1975.

Hasybi, Kumpulan Soal-Jawab, Cet. ke-1Jakarta: Bulan Bintang, 1973.

Hasybi, Pedoman Zakat, Cet. Ke-5 Jakarta: Bulan Bintang, 1984.

Hasybi, Pokok-pokok Ilmu Dirayah Hadis, Cet. Ke-5, jilid 1, Jakarta: Bulan Bintang, 1981.

Hasybi, Sejarah dan Pengantar Ilmu Al-Qur'an/Tafsir, Cet.ke-Vll, Jakarta: Bulan Bintang, 1980.

Hasybi. Sejarah dan Pengantar Ilmu Hadis, Cet Ke-6, Jakarta: Bulan Bintang, 1974.

Qadir, Abdurrachman, Zakat Dalam Dimensi Mahdhah dan Sosial (Jakarta: PT Raja Grafindo Persada, 2001).

Maarif, Moh. Ahyar, Baitul Mal pada Masa Rasulullah Saw dan Khulafaur AlRasyidin. Asy-Syari'ah: Jurnal Hukum Islam, 2019.

Shiddieqy, Hasybi Ash. Mu'djizat al-Qur'an (Jakarta: Bulan Bintang, 1994).

Shiddieqy, Muhammad Hasbi Ash, Pedoman Zakat, Cet.ke-1, Edisi ke-3, Semarang: Pustaka Rizki Putra, 2009.

Shiddieqy, Muhammad Hasbi Ash-, Pedoman Zakat, Semarang: Pustaka Rizki Putra, 2009.

Shiddieqy, Nourouzzaman, Fiqih Indonesia, Yogyakarta: Pustaka Pelajar, 1997.

Shiddieqy, Nouruzzaman. Fiqh Indonesia, Penggagas dan Gagasannya, Cet. ke-1 Yogyakarta: Pustaka Pelajar, 2001.

Shiddieqy, Tengku Muhammad Hasbi Ash, Pedoman Zakat, Semarang: Pustaka Rizki Putra, 2009.

Sulaiman, Rusydi, Zakat dan Keadilan Sosial: Optimalisasi Pengelolaan Zakat Profesi untuk Pemberdayaan Umat, Asy-Syari'ah: Jurnal Ilmu Syari'ah dan Perbangkan Islam, Vol. 6, No. 2, Desember 202.

Supian, Aan, Kontribusi Pemikiran Hasbi Ash-Shiddieqy Dalam Bidang Fikih, Media Syariah, Vol. XIV No. 2 Juli - Desember 2012.

Usman, Suparman, Hukum Islam (Asas-asas pengantar studi hukum Islam dalam tata hukum Indonesia), Cet. II Jakarta: Gaya Media Pratama, 2002. 